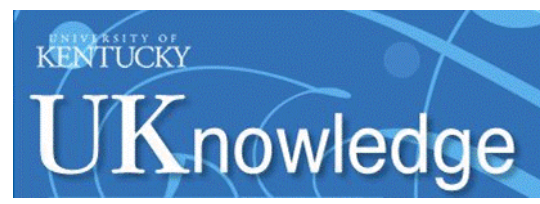

University of Kentucky

UKnowledge

Toxicology and Cancer Biology Faculty

Publications

Toxicology and Cancer Biology

2-5-2016

\title{
Stable Isotope Resolved Metabolomics Studies in ex vivo Tissue Slices
}

Teresa W-M Fan

University of Kentucky, teresa.fan@uky.edu

Andrew N. Lane

University of Kentucky, andrew.lane@uky.edu

Richard M. Higashi

University of Kentucky, rick.higashi@uky.edu

Follow this and additional works at: https://uknowledge.uky.edu/toxicology_facpub

Part of the Medical Toxicology Commons

Right click to open a feedback form in a new tab to let us know how this document benefits you.

\section{Repository Citation}

Fan, Teresa W-M; Lane, Andrew N.; and Higashi, Richard M., "Stable Isotope Resolved Metabolomics Studies in ex vivo Tissue Slices" (2016). Toxicology and Cancer Biology Faculty Publications. 46.

https://uknowledge.uky.edu/toxicology_facpub/46

This Article is brought to you for free and open access by the Toxicology and Cancer Biology at UKnowledge. It has been accepted for inclusion in Toxicology and Cancer Biology Faculty Publications by an authorized administrator of UKnowledge. For more information, please contact UKnowledge@lsv.uky.edu. 


\section{Stable Isotope Resolved Metabolomics Studies in ex vivo Tissue Slices}

Notes/Citation Information

Published in Bio-Protocol, v. 6, no. 3, article e1730, p. 1-12.

(C) 2016 Bio-protocol LLC

The copyright holders have granted the permission for posting the article here. 


\section{Stable Isotope Resolved Metabolomics Studies in ex vivo Tlssue Slices}

Teresa W-M. Fan ${ }^{*}$, Andrew N. Lane and Richard M. Higashi

Center for Environmental Systems Biochemistry, Dept. Toxicology and Cancer Biology and Markey Cancer Center, 789 S. Limestone St., Lexington, USA

*For correspondence: twmfan@gmail.com

[Abstract] An important component of this methodology is to assess the role of the tumor microenvironment on tumor growth and survival. To tackle this problem, we have adapted the original approach of Warburg (Warburg, 1923), by combining thin tissue slices with Stable Isotope Resolved Metabolomics (SIRM) to determine detailed metabolic activity of human tissues. SIRM enables the tracing of metabolic transformations of source molecules such as glucose or glutamine over defined time periods, and is a requirement for detailed pathway tracing and flux analysis. In our approach, we maintain freshly resected tissue slices (both cancerous and non- cancerous from the same organ of the same subject) in cell culture media, and treat with appropriate stable isotope-enriched nutrients, e.g. ${ }^{13} \mathrm{C}_{6}$-glucose or ${ }^{13} \mathrm{C}_{5}$,

${ }^{15} \mathrm{~N}_{2}$-glutamine. These slices are viable for at least $24 \mathrm{~h}$, and make it possible to eliminate systemic influence on the target tissue metabolism while maintaining the original 3D cellular architecture. It is therefore an excellent pre-clinical platform for assessing the effect of therapeutic agents on target tissue metabolism and their therapeutic efficacy on individual patients (Xie et al., 2014; Sellers et al., 2015).

\section{Materials and Reagents}

1. $25 \mathrm{ml}$ T Flasks NC vent cap (SARSTEDT AG \& Co, catalog number: 83.1810 .002 )

2. Portable container for liquid nitrogen (Nalgene plastic dewar) (Thermo Fisher Scientific, catalog number: S34074C)

3. Sterile syringes and needles (Thermo Fisher Scientific, catalog number: 10142534)

4. Disposable transfer pipets (Samco fine tip, $1 \mathrm{ml}$ ) (VWR International, catalog number: 16001192)

5. Aerosol barrier tips for $1 \mathrm{ml}$ and $1-200 \mu \mathrm{l}$ (Thermo Fisher Scientific, catalog number: 02-707-42)

6. Screw cap plastic vials $(2 \mathrm{ml})$ color coded caps (yellow, blue, green and red) (USA Scientific, catalog number: 1420-8706, 1420-8701, 1420-8702 and 1420-9704)

7. Snap top plastic vials $(1.5 \mathrm{ml})$ (USA Scientific, catalog number: 1615-5510)

8. $15 \mathrm{ml}$ Falcon tubes (SARSTEDT AG \& Co, catalog number: 62.554 .205 )

9. Dialyzed, sterile filtered fetal bovine serum (FBS) (free of serum metabolites),10-12 kDa (Atlanta Biochemical, catalog number: S12650)

10. Tracer examples: ${ }^{13} \mathrm{C}_{6}$-glucose,${ }^{13} \mathrm{C}_{2}$-1, 2-glucose, ${ }^{13} \mathrm{C}_{5},{ }^{15} \mathrm{~N}_{2}$-glutamine 
11. Sources: ${ }^{13} \mathrm{C}_{6}$-glucose/D-glucose ([U- $\left.{ }^{13} \mathrm{C}\right], 99 \%$ ) (Cambridge Isotope Laboratories, catalog number: CLM-1396-CTM), ${ }^{13} \mathrm{C}_{2}-1,2$ glucose/D-glucose $\left(1,2-{ }^{13} \mathrm{C}_{2}, 99 \%\right)$ (Cambridge Isotope Laboratories, catalog number: CLM-504), ${ }^{13} \mathrm{C}_{5},{ }^{15} \mathrm{~N}_{2}$-glutamine/ L-glutamine $\left({ }^{13} \mathrm{C}_{5}, 99 \% ;{ }^{15} \mathrm{~N}_{2}, 99 \%\right.$ ) (Cambridge Isotope Laboratories, catalog number: CNLM-1275) or Isotec: $\mathrm{D}-{ }^{13} \mathrm{C}_{6}$-glucose (Sigma-Aldrich, catalog number: 660663$),{ }^{13} \mathrm{C}_{2}-1,2$ glucose (Sigma-Aldrich, catalog number: 661422), L-Glutamine- ${ }^{13} \mathrm{C}_{5},{ }^{15} \mathrm{~N}_{2}$ (Sigma-Aldrich, catalog number: 607983)

12. Penicillin + Streptomycin: GE Healthcare PEN/STREP/FUNGIZONE $100 \mathrm{ml}$ (Thermo Fisher Scientific, catalog number: SV3007901)

13. Protocol ${ }^{\mathrm{TM}} 10 \%$ Neutral buffered formalin (Thermo Fisher Scientific, catalog number: 032-059)

14. $25 \%(\mathrm{w} / \mathrm{v})$ sterile filtered ${ }^{13} \mathrm{C}$ glucose $(0.2 \mu \mathrm{m})$ in PBS (Stock solution-can be frozen, aliquoted, and stored at $4{ }^{\circ} \mathrm{C}$ )

15. Liquid nitrogen

16. $70 \%$ ethanol $(\mathrm{v} / \mathrm{v})$

17. $60 \%$ acetonitrile in water (v/v) (Sigma-Aldrich, catalog number: L010400)

18. Sodium chloride $(\mathrm{NaCl})$ (Thermo Fisher Scientific, catalog number: S271-1)

19. Potassium chloride (KCl) (Sigma-Aldrich, catalog number: P9541)

20. Sodium phosphate dibasic $\left(\mathrm{Na}_{2} \mathrm{HPO}_{4}\right)$ (Sigma-Aldrich, catalog number: S0876)

21. Potassium phosphate monobasic $\left(\mathrm{KH}_{2} \mathrm{PO}_{4}\right)$ (Sigma-Aldrich, catalog number: P9791)

22. Amino acids: Glycine, L-Arginine, L-Asparagine, L-Aspartic acid, L-Cystine $2 \mathrm{HCl}$, L-Glutamic Acid, L-Glutamine, L-Histidine, L-Hydroxyproline, L-Isoleucine, L-Leucine, L-Lysine hydrochloride, L-Methionine, L-Phenylalanine, L-Proline, L-Serine, L-Threonine, L-Tryptophan, L-Tyrosine disodium salt dehydrate, L-Valine

23. Vitamins: Biotin, Choline chloride, D-Calcium pantothenate, Folic Acid, i-Inositol, Niacinamide, Para-Aminobenzoic Acid, Pyridoxine hydrochloride, Riboflavin, Thiamine hydrochloride, Vitamin B12

24. Calcium nitrate $\left[\mathrm{Ca}\left(\mathrm{NO}_{3}\right)_{2} 4 \mathrm{H}_{2} \mathrm{O}\right]$

25. Magnesium sulfate $\left(\mathrm{MgSO}_{4}\right)$

26. Glutathione (reduced)

27. Phenol Red

28. Relevant medium (e.g. DMEM, RPMI, other defined medium) which lacks the tracer of interest:

a. Dulbecco's Modified Eagle's Medium (DMEM) is a powder formula, free of glucose, glutamine, pyruvate bicarbonate, and phenol red, giving considerable flexibility in formulation for SIRM studies (Sigma-Aldrich, catalog number: D5030) (see Recipes) 
b. RPMI 1640 is a liquid medium free of glucose and glutamine, but contains bicarbonate and phenol red (MP Biomedicals, catalog number: 091646854) (see Recipes)

29. $0.2 \mu \mathrm{m}$ sterile filtered Phosphate Buffered Saline (PBS) (see Recipes)

30. Medium composition for $0.2 \%{ }^{13} \mathrm{C}_{6}$-glucose, $2 \mathrm{mM}{ }^{12} \mathrm{C}$-Gln (100 ml) (see Recipes)

31. Medium composition for $0.2 \%{ }^{12} \mathrm{C}$ glucose, $2 \mathrm{mM}{ }^{13} \mathrm{C}_{5},{ }^{15} \mathrm{~N}_{2}$ - $\mathrm{Gln}$ (100 ml) (see Recipes)

\section{Equipment}

1. Class II Biosafety Hood

2. Trigas incubator with oxygen sensor and $\mathrm{CO}_{2}$ sensor (Thermo Fisher Scientific, model: Hera cell 150i)

3. Sterilized rocker (Rotoshake Genie) (Scientific Industries, model: SI-1100)

4. Liquid nitrogen freezer for storage

5. $\mathrm{K}_{2}$-EDTA vacutainers ("purple top") (BD, catalog number: 366643 )

6. Refrigerated centrifuge with swing out rotor that can accept vacutainers [e.g. Sorvall Legend X1R (Thermo Fisher Scientific, catalog number: 75-004-261) with a rotor (Thermo Fisher Scientific, catalog number: 75003181)]

7. Pipettors (variable size ranges) (USA Scientific ErgoOne)

8. Weck Knife/Dermatome (George Tiemann \& Co., catalog number: 222-5-523)

9. Weigh boats (Thermo Fisher Scientific, catalog number: 08732113 and 08732115 )

10. 4-place balance (Thermo Fisher Scientific, Mettler-Toledo, catalog number: 0133525)

11. Ice bucket (Thermo Fisher Scientific, catalog number: 02-591-44)

12. Sharp dissecting scissors (Thermo Fisher Scientific, catalog number: 08940)

13. Excelta ${ }^{\mathrm{TM}}$ Plastic Tweezers (Thermo Fisher Scientific, catalog number: 17-456-066)

14. Digital camera

\section{Procedure}

A. Tissue procurement

All tissue must be procured under an IRB approved protocol. As live human tissue is handled, all personnel must undergo and maintain biosafety, HIPAA and CITI certifications. An overview of the whole process is given in Scheme 1. 


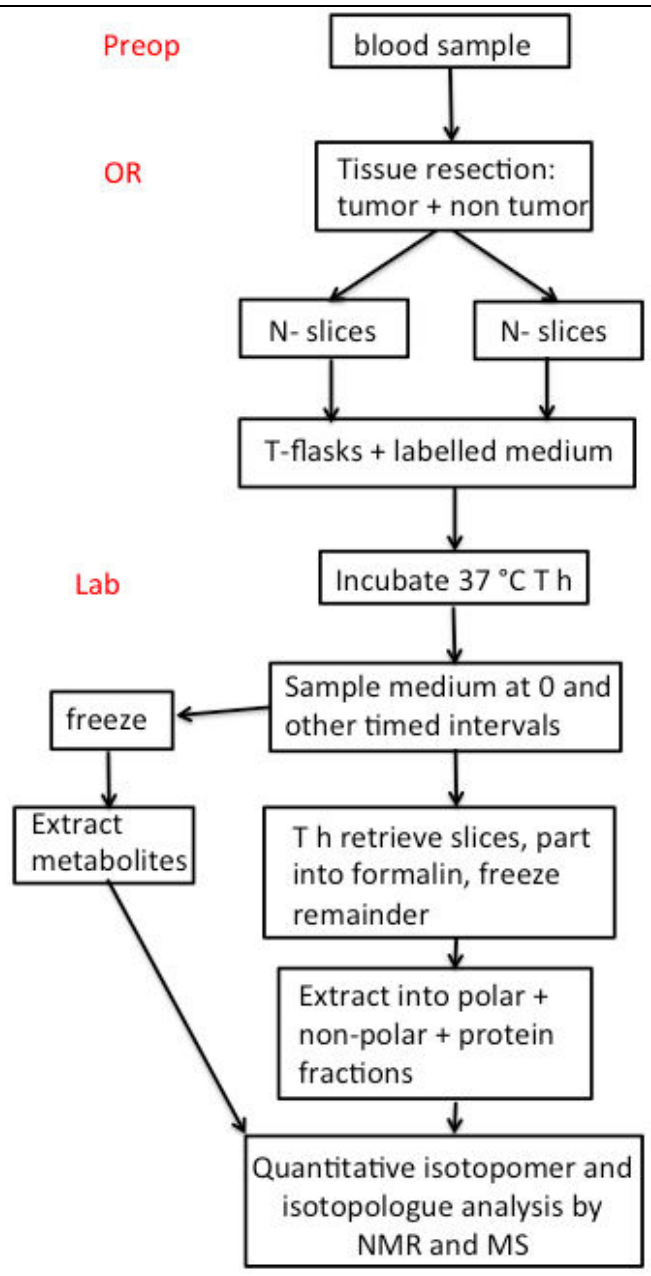

Scheme 1. FlowChart. Preop: Preoperative room; OR: Operating Room. The number of thin slices to be taken depends on the size of the tumor. A piece of tissue is also flash frozen in the OR, and additional tissue is placed in formalin for pathological analysis.

1. Blood samples provide overall information about the metabolic status of the individual subjects, and the buffy coat can be used for extracting DNA or RNA for sequence analysis.

2. A $10 \mathrm{ml}$ sample of blood should be drawn preoperatively into a purple top vacutainer ( $\mathrm{K}_{2}$-EDTA) preoperatively. Other anticoagulants such as citrate or heparin should not be used as they interfere with metabolic assays. A blood sample should also be drawn perioperatively after resection. The blood is inverted twice to ensure dissolution of the EDTA, and kept on ice immediately after blood draw. The blood should be separated into packed red cells, buffy coat and plasma within 30 min by centrifuging at 3,500 $\times \mathrm{g}$ for $15 \mathrm{~min}$ at $4{ }^{\circ} \mathrm{C}$ in a swing out rotor.

Subsequent operations should be carried out in a BSL2 ${ }^{+}$biosafety cabinet.

Note: We use the following color codes for storage: Red $=$ whole blood, yellow = plasma, green $=$ buffy coat, blue $=$ urine .

3. Plasma is aspirated into prechilled sterile $2 \mathrm{ml} \mathrm{screw}$ cap vials at $1 \mathrm{ml}$ aliquots and flash 
frozen in liquid $\mathrm{N}_{2}$. Buffy coat is aspirated using a wide mouth plastic pipette into a $2 \mathrm{ml}$ screwcap vial and flash frozen in liquid $\mathrm{N}_{2}$.

4. These experiments have been carried out on fresh slices of paired cancerous (CA) and non-cancerous (NC) lung tissues resected from non-small cell lung cancer (Xie et al., 2014) and pancreatic cancer patients. Upon resection, thin slices (0.5-1 mm thick) of tissue are excised from the surface of visually non-necrotic or fibrotic tumor regions using a Weck microtome in the Operating Room (OR), within approximately 5-10 min of resection. Roughly $1 \mathrm{~cm}^{2}$ tissue is targeted (see Figure $1 \mathrm{~A}$ ). Control non-cancerous tissue from a distant $(>10 \mathrm{~cm})$ region is obtained similarly. A pathologist on-site inspects the CA and NC tissue specimens. Highly necrotic tissue is discarded.

5. At the same time, a small piece of bulk CA tissue should be placed in DMEM or other appropriate medium kept room temperature for implantation into a recipient NSG mouse as patient-derived xenograft or PDX. A small piece each of CA and NC tissues is soaked in formalin for pathological examination or flash frozen in liquid $N_{2}$ for image-based metabolic analysis.

6. Where tissue acquisition in the $\mathrm{OR}$ is impractical (such as colorectal or breast cancer resections), the slices can be prepared in the pathology laboratory located close to the OR. For comparison with freshly resected tissue, speed is essential as metabolism is rapidly changing. Whenever feasible, tissue freezing should be performed in the OR.

7. The slices are placed into a drop of sterile PBS on two sterilized weigh boats to prevent sticking and for spreading slices evenly. Each weight boat is pre-numbered for CA or NC slices. The tissues on weight boats are then photographed. Each slice is rinsed briefly with sterile PBS, blotted (twice) and then carefully placed into pre-numbered (using ethanol-resistant marker pen) pre-tared (tare weight recorded) T25-flasks containing $10 \mathrm{mI}$ DMEM (or other relevant medium) with the appropriate tracer (e.g. 10 $\mathrm{mM}{ }^{13} \mathrm{C}_{6}$-glucose or $2 \mathrm{mM}{ }^{13} \mathrm{C}_{5},{ }^{15} \mathrm{~N}_{2}$-glutamine), $10 \%$ dialyzed FBS (as needed), and $1 \mathrm{x}$ penicillin + streptomycin. The flasks with slices are brought to the culture room as soon as possible and sprayed with $70 \%$ ethanol, and wiped dry before placing them in the Biosafety hood.

8. Pipet $200 \mu \mathrm{l}$ culture media from each flask into $1.5 \mathrm{ml}$ snap-cap tubes ( $\mathrm{t}_{0}$-time zero media samples). Centrifuge for $10 \mathrm{~min}$ at $10,000 \times \mathrm{g}$ at $4{ }^{\circ} \mathrm{C}$ to remove tissue debris. Transfer $100 \mu \mathrm{l}$ to tared $1.5 \mu \mathrm{l}$ snap-cap tube for metabolite extraction and weigh the media transferred. Transfer the remaining media to a $1.5 \mathrm{ml}$ screw-cap tube for long-term storage at $-80^{\circ} \mathrm{C}$.

9. Weigh flasks in a 2-place balance inside the Biosafety hood and record weight on the flask.

10. Transfer flasks to a $\mathrm{CO}_{2}$ incubator containing a rocker set to low amplitude rocking (sufficient to ensure that the liquid moves over the slices without non-laminar flow) Figure $1 \mathrm{~B}$ ) set to $37{ }^{\circ} \mathrm{C}$ and $5 \% \mathrm{CO}_{2}$, with oxygen set to the desired level (e.g. $20 \%$, $1 \%)$. 
11. The flasks are continuously and gently rocked for 24 to $48 \mathrm{~h}$ for gas exchange and to maintain constant nutrient supplies at the tissue surface, while avoiding local buildup of waste products such as acids.

12. As needed, the medium can be refreshed every $12 \mathrm{~h}$, and sampled at $0,6,12,24 \ldots \mathrm{h}$ for analysis of nutrient uptake and waste production. The flasks are weighed before and after each medium sampling point and flask weights are recorded on the flasks.

B. Tissue Harvesting

1. After $24 \mathrm{~h}$ incubation, weigh flasks.

2. Place flasks on ice immediately after removing from the incubator to minimize further metabolism. Up to 6 flasks can be harvested at a time. Keep tissue slices on ice as much as possible during harvest.

3. Using a transfer pipet, aspirate and transfer the conditioned media into $15-\mathrm{ml}$ conical centrifuge tubes.

4. Centrifuge media for $15 \mathrm{~min}$ at 3,500 to $4,690 \times \mathrm{g}, 4{ }^{\circ} \mathrm{C}$ to remove any particulates and debris.

5. Pipet $100 \mu \mathrm{T}_{24}$ media supernatant into 1.5-ml snap-cap tubes for metabolite extraction.

6. Pipet $1 \mathrm{ml}$ media aliquot into $2-\mathrm{ml} \mathrm{screw}$-cap tubes for long-term storage at $-80^{\circ} \mathrm{C}$.

7. The remaining medium is stored separately in a $7 \mathrm{ml}$ vial at $-80^{\circ} \mathrm{C}$ for purposes such as exosome isolation.

8. Invert and tap the flask to move the tissue slices into the cap or neck region of the flask for retrieval. Keep flask inverted on ice.

9. Wash tissue slices $3 x$ consecutively in ice-cold $10 \mathrm{ml}$ cold PBS each in a $50 \mathrm{ml}$ beaker.

10. Blot dry the tissue slices on Kimwipe and photograph the flattened slice on a small weigh boat.

11. Weigh the whole tissue slice on small weigh boats and record the weight.

12. Split a very small piece for preservation in $1 \mathrm{ml}$ buffered formalin in a $1.5 \mathrm{ml}$ snap-cap tube for histology. The remaining tissue slice is split evenly and each piece should weigh no more than $20-30 \mathrm{mg}$ by wet weight to facilitate tissue homogenization and extraction efficiency. Immediately after weighing, each piece is flash-frozen in liq. $\mathrm{N}_{2}$ and placed in a pre-liq. $\mathrm{N}_{2}$ chilled $1.5-\mathrm{ml}$ snap-cap tube for long-term storage at $-80{ }^{\circ} \mathrm{C}$.

13. After $6-8 \mathrm{~h}$ in formalin, replace the formalin with $70 \%$ ethanol for the tissue pieces prepared for histology.

14. Homogenize tissues in cold $60 \%$ acetonitrile $(\mathrm{v} / \mathrm{v})$ and extract tissue homogenates for metabolite analyses according to standardized protocols (Fan, 2012; Fan, 2010) before analyses using stable isotope-resolving analytical techniques (e.g. NMR and MS) (Fan, 2012) (Figure 1C) (Lane et al., 2008).

15. This Protocol describes the procedure for stable isotope labeling of thin tissue slices. SIRM analysis involves the quantification of isotopomers (by NMR) and isotopologues 
(MS) that result from metabolic transformations of source molecules $\left(e . g .{ }^{13} \mathrm{C}\right.$ glucose or ${ }^{13} \mathrm{C},{ }^{15} \mathrm{~N}$ Glutamine) in cells or tissue (Figure $1 \mathrm{C}$ ). The techniques of SIRM analysis by NMR and mass spectrometry are described in detail in Sellers et al. (2015); Lane et al. (2008) and Fan et al. (2012).

\section{Representative data}

A
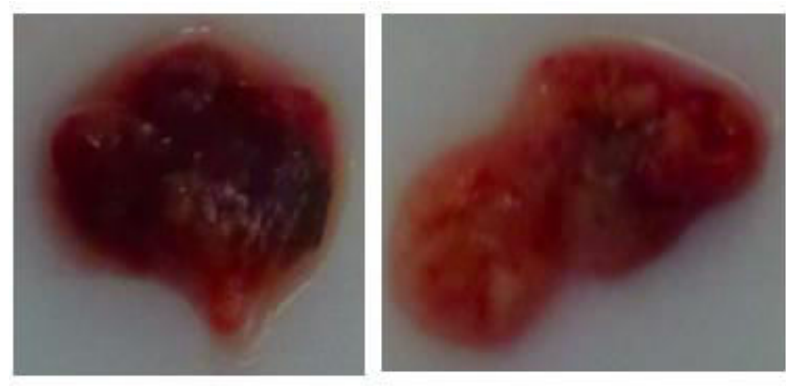

\section{Ex vivo tissue slices}

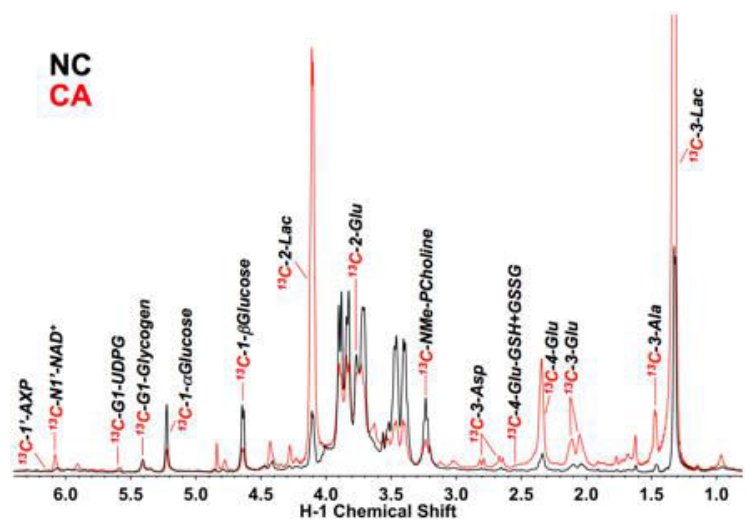

B

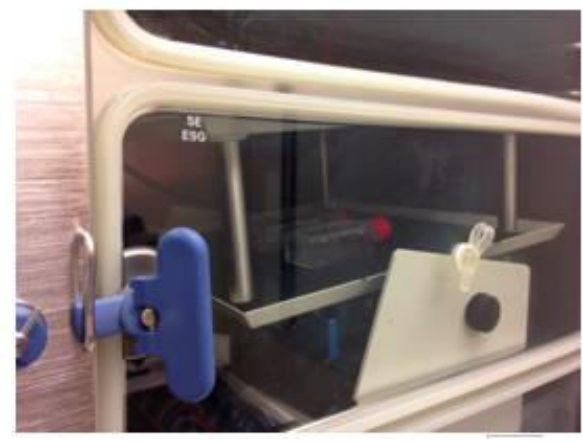

Figure 1 Example ex vivo tissue slice experiment. A. Example thin slices of non-cancerous lung tissue (NC, left) adjacent to a lung adenocarcinoma (CA, right); $B$. T25-flasks on a rocker inside a $\mathrm{CO}_{2}$ incubator; C. Representative $1 \mathrm{D}{ }^{1} \mathrm{H}\left\{{ }^{13} \mathrm{C}\right\} \mathrm{HSQC}$ NMR spectra (recorded at $14.1 \mathrm{~T}, 15^{\circ} \mathrm{C}$ ) of extracts of $\mathrm{CA}$ versus $\mathrm{NC}$ lung slices from an non small cell lung cancer (NSCLC) patient incubated for $24 \mathrm{~h}$ in the presence of $10 \mathrm{mM}$ ${ }^{13} \mathrm{C}_{6}$-glucose. The tissue slices were pulverized and extracted as described (Sellers et al., 2015; Fan, 2012) which produces three phases- an upper aqueous phase containing polar metabolites, a lower organic phase containing non-polar metabolites (mainly lipids) and an interfacial phase that contains protein. Here the upper phase was lyophilized and redissolved in a phosphate buffer containing $50 \% D_{2} \mathrm{O}$ and $25 \mathrm{nmol}$ DSS- $\mathrm{d}_{6}$ that serves both as a chemical shift reference and a concentration standard (Fan and Lane, 2013). The HSQC spectrum detects protons attached directly to ${ }^{13} \mathrm{C}$, and thus gives a readout of the metabolites that have incorporated ${ }^{13} \mathrm{C}$ from the source molecule (glucose in this instance). The spectra of cancer and non-cancerous tissues are recorded under identical conditions, 
and the absolute intensities are normalized to the tissue protein weight. Peak areas were determined using peak fitting functions in MNOVA (Mestrelab Research, Santiago de Compostela, Spain)

Enhanced production of various ${ }^{13} \mathrm{C}$ labeled metabolites in the CA tissue slice is evident, including ${ }^{13} \mathrm{C}$-lactate (Lac), which is consistent with the Warburg effect or accelerated glycolysis in tumor tissues (Warburg, 1956).

\section{$\underline{\text { Notes }}$}

1. These procedures have been tested on freshly resected NSCLC and pancreatic cancer, as well as in patient derived mouse xenografts. Other tissues may need experimentation with the composition of the medium and length of incubation period for metabolic viability.

2. Larger or inflammatory tumors may have substantial areas of necrosis or fibrosis that need to be avoided.

3. A Weck microtome is hand held, but with practice the surgeons can reproducibly produce slices $<1 \mathrm{~mm}$ thick. Slice thickness is easily estimated by measuring the area of the slice from a photograph and from the wet weigh as the average thickness $h=$ weight/area.

4. Some tumors are highly mucilaginous and are more difficult to slice reproducibly.

5. An alternative to a Weck microtome is a vibrating microtome, which can reproducibly generate thinner slices from firm but not soft tissues $\left(\mathrm{cf}^{10}\right)$, but is much slower. Very thin slices (100-200 $\mu \mathrm{m})$ may show a proportionately larger wounding response and are more fragile.

6. As many tumors are heterogeneous not only in the cancer/stromal content in different regions of the tumor but also in terms of genetics, it is advisable to obtain multiple slices from the tumor to cover this heterogeneity. This also makes histopathological examination of each slice critically important.

7. The margins of some tumors are not obvious without pathological examination. Tissue proximal to the tumor as well as distal from the tumor should be sampled for comparison.

\section{Recipes}

1. DMEM and RPMI Medium 1640

For SIRM studies, the glutamine or glucose free version of the medium should be used, with supplementation of the appropriate concentration of ${ }^{13} \mathrm{C}$-enriched precursors in the base medium. 


\begin{tabular}{|c|c|c|c|c|}
\hline COMPONENTS & $\begin{array}{l}\text { Molecular } \\
\text { Weight }\end{array}$ & $\begin{array}{l}\text { Concentration } \\
\text { (mg/L) }\end{array}$ & $\begin{array}{l}\text { Molarity (mM) } \\
\text { RPMI }\end{array}$ & $\begin{array}{l}\text { Molarity }(\mathrm{mM}) \\
\text { DMEM }\end{array}$ \\
\hline \multicolumn{5}{|l|}{ Amino Acids } \\
\hline Glycine & 75 & 10 & 0.133 & 0.40 \\
\hline L-Arginine & 174 & 200 & 1.15 & 0.483 \\
\hline L-Asparagine & 132 & 50 & 0.379 & - \\
\hline L-Aspartic acid & 133 & 20 & 0.150 & - \\
\hline L-Cystine $2 \mathrm{HCl}$ & 313 & 65 & 0.208 & $0 / 0.2$ \\
\hline L-Glutamic Acid & 147 & 20 & 0.136 & - \\
\hline L-Glutamine & 146 & 300 & 2.05 & 2 \\
\hline L-Histidine & 155 & 15 & 0.0968 & 0.27 \\
\hline L-Hydroxyproline & 131 & 20 & 0.153 & - \\
\hline L-Isoleucine & 131 & 50 & 0.382 & 0.8 \\
\hline L-Leucine & 131 & 50 & 0.382 & 0.8 \\
\hline L-Lysine hydrochloride & 146 & 40 & 0.274 & 1.0 \\
\hline L-Methionine & 149 & 15 & 0.101 & 0.2 \\
\hline L-Phenylalanine & 165 & 15 & 0.0909 & 0.4 \\
\hline L-Proline & 115 & 20 & 0.174 & - \\
\hline L-Serine & 105 & 30 & 0.286 & 0.4 \\
\hline L-Threonine & 119 & 20 & 0.168 & 0.8 \\
\hline L-Tryptophan & 204 & 5 & 0.0245 & 0.078 \\
\hline $\begin{array}{l}\text { L-Tyrosine disodium salt } \\
\text { dihydrate }\end{array}$ & 261 & 29 & 0.111 & 0.4 \\
\hline L-Valine & 117 & 20 & 0.171 & 0.8 \\
\hline \multicolumn{5}{|l|}{ Vitamins } \\
\hline Biotin & 244 & 0.2 & 0.000820 & \\
\hline Choline chloride & 140 & 3 & 0.0214 & 0.0285 \\
\hline D-Calcium pantothenate & 477 & 0.25 & 0.000524 & 0.008 \\
\hline Folic Acid & 441 & 1 & 0.00227 & 0.009 \\
\hline i-Inositol & 180 & 35 & 0.194 & .04 \\
\hline
\end{tabular}




\begin{tabular}{|c|c|c|c|c|}
\hline Niacinamide & 122 & 1 & 0.00820 & 0.033 \\
\hline Para-Aminobenzoic Acid & 137 & 1 & 0.00730 & \\
\hline Pyridoxine hydrochloride & 206 & 1 & 0.00485 & .019 \\
\hline Riboflavin & 376 & 0.2 & 0.000532 & .001 \\
\hline Thiamine hydrochloride & 337 & 1 & 0.00297 & .012 \\
\hline Vitamin B12 & 1,355 & 0.005 & 0.0000037 & - \\
\hline \multicolumn{5}{|l|}{ Inorganic Salts } \\
\hline $\begin{array}{ll}\text { Calcium } & \text { nitrate } \\
\left(\mathrm{Ca}\left(\mathrm{NO}_{3}\right)_{2} \cdot 4 \mathrm{H}_{2} \mathrm{O}\right) & \end{array}$ & 236 & 100 & 0.424 & \\
\hline $\begin{array}{ll}\text { Magnesium } & \text { Sulfate } \\
\left(\mathrm{MgSO}_{4}\right) \text { (anhyd.) } & \end{array}$ & 120 & 48.84 & 0.407 & \\
\hline Potassium Chloride $(\mathrm{KCl})$ & 75 & 400 & 5.33 & \\
\hline $\begin{array}{l}\text { Sodium } \quad \text { Bicarbonate } \\
\left(\mathrm{NaHCO}_{3}\right)\end{array}$ & 84 & 2,000 & 23.81 & 44 \\
\hline Sodium Chloride $(\mathrm{NaCl})$ & 58 & 6,000 & 103.45 & \\
\hline $\begin{array}{l}\text { Sodium Phosphate dibasic } \\
\left(\mathrm{Na}_{2} \mathrm{HPO}_{4} \cdot 7 \mathrm{H}_{2} \mathrm{O}\right)\end{array}$ & 268 & 1,512 & 5.64 & \\
\hline \multicolumn{5}{|l|}{ Other Components } \\
\hline Glutathione (reduced) & 307 & 1 & 0.00326 & \\
\hline Phenol Red & 376.4 & 5 & 0.0133 & \\
\hline
\end{tabular}

2. $10 x$ PBS

Sources of reagents are given in the Materials Section

$80 \mathrm{~g} \mathrm{NaCl}$

$2 \mathrm{~g} \mathrm{KCl}$

$14.4 \mathrm{~g} \mathrm{Na}_{2} \mathrm{HPO}_{4}$ anhydrous

$2.4 \mathrm{~g} \mathrm{KH}_{2} \mathrm{PO}_{4}$ anhydrous

Dissolve in $950 \mathrm{ml} 18 \mathrm{MOhm}$ water, $\mathrm{pH}$ to 7.4 , make to $1 \mathrm{~L}$, sterile filter $(0.2 \mu \mathrm{m})$

3. Medium composition for $0.2 \%{ }^{13} \mathrm{C}_{6}$-glucose, $2 \mathrm{mM}{ }^{12} \mathrm{C}$-Gln $(100 \mathrm{ml})$

$89.2 \mathrm{ml}$ base medium minus tracer (e.g. glucose-free version) (89\% concentration of nutrients)

$10 \mathrm{ml}$ sterile filtered dialyzed FBS (10\% FBS)

$0.8 \mathrm{ml} 25 \%$ sterile filtered ${ }^{13} \mathrm{C}_{6}$ glucose $(0.2 \mu \mathrm{m})$ in PBS (10.75 mM glucose final)

$1 \mathrm{ml}$ 100x streptomycin/penicillin stock

4. Medium composition for $0.2 \%{ }^{12} \mathrm{C}$ glucose, $2 \mathrm{mM}{ }^{13} \mathrm{C}_{5},{ }^{15} \mathrm{~N}_{2}-\mathrm{G} \ln (100 \mathrm{ml})$ 
$88 \mathrm{ml}$ base medium minus tracer (glutamine-free version) (88\% concentration of all nutrients)

$10 \mathrm{ml}$ sterile filtered dialyzed FBS (10\% FBS)

$1 \mathrm{ml} 0.2 \mathrm{M}$ sterile filtered ${ }^{13} \mathrm{C}_{5},{ }^{15} \mathrm{~N}_{2}$-glutamine $(0.2 \mu \mathrm{m})$ in PBS (2 mM final)

$1 \mathrm{ml}$ 100x streptomycin/penicillin stock

For hormone sensitive tissues, activated carbon-stripped FBS may be used.

For other concentrations of FBS, adjust the volumes of the FBS and base medium accordingly.

Note: Glutamine stock should be made fresh or stored at $-20{ }^{\circ} \mathrm{C}$ in small aliquots to avoid repeated freeze and thawing. It forms pyroglutamate on storage in solution even at neutral $\mathrm{pH}$ at higher temperatures.

\section{Acknowledgments}

This work was supported in part by the following grants: NIH P01 CA163223-01A1, NIH 5R01ES022191-04, NIH 3R01ES022191-04S1, NIH 1U24DK097215-01A1, and the Kentucky Challenge for Excellence. This protocol has been developed based on work described in Xie et al. (2014); Sellers et al. (2015) and Bousamra et al. (2012). The authors declare no conflicts of interest.

\section{References}

1. Bousamra, M., Day, J., Fan, T. W., Higashi, R. M., Kloecker, G., Lane, A. N. and Miller, D. M. (2012). Clinical aspects of metabolomics. In: The Handbook of Metabolomics. Humana, Vol. 17.

2. Fan, T. W. (2012). Considerations of sample preparation for metabolomics investigation. Handbook of Metabolomics 17.

3. Fan, T. W. (2010). Metabolomics-edited transcriptomics analysis (meta). In: McQueen, C. A. (ed). Comprehensive Toxicology. Academic Press Vol. 2 685-706.

4. Fan, T. W. and Lane, A. N. (2013). Assignment strategies for NMR resonances in metabolomics research. In: Lutz, N., Sweedler, J. V. and Weevers, R. A. (eds). Methodologies for Metabolomics: Experimental Strategies and Techniques. Cambridge University Press.

5. Fan, T. W., Lorkiewicz, P. K., Sellers, K., Moseley, H. N., Higashi, R. M. and Lane, A. N. (2012). Stable isotope-resolved metabolomics and applications for drug development. Pharmacol Ther 133(3): 366-391.

6. Lane, A. N., Fan, T. W. and Higashi, R. M. (2008). Isotopomer-based metabolomic analysis by NMR and mass spectrometry. Methods Cell Biol 84: 541-588.

7. Sellers, K., Fox, M. P., Bousamra, M., 2nd, Slone, S. P., Higashi, R. M., Miller, D. M., Wang, Y., Yan, J., Yuneva, M. O., Deshpande, R., Lane, A. N. and Fan, T. W. (2015). 
Pyruvate carboxylase is critical for non-small-cell lung cancer proliferation. $J$ Clin Invest 125(2): 687-698.

8. Warburg, O. (1923). Versuche an überlebendem Carcinomgewebe (Methoden). Biochem Zeitschr 142, 317-333.

9. Warburg, O. (1956). On the origin of cancer cells. Science 123(3191): 309-314.

10. Xie, H., Hanai, J., Ren, J. G., Kats, L., Burgess, K., Bhargava, P., Signoretti, S., Billiard, J., Duffy, K. J., Grant, A., Wang, X., Lorkiewicz, P. K., Schatzman, S., Bousamra, M., 2nd, Lane, A. N., Higashi, R. M., Fan, T. W., Pandolfi, P. P., Sukhatme, V. P. and Seth, P. (2014). Targeting lactate dehydrogenase--a inhibits tumorigenesis and tumor progression in mouse models of lung cancer and impacts tumor-initiating cells. Cell Metab 19(5): 795-809.

11. Zimmermann, M., Sebastian Lange, S., Lampe, J., Smirnow, I., Bitzer, M. and Lauer, U. M. (2012). Precision-cut slices of normal and tumorous liver tissues generated with the Leica VT1200 S vibrating blade microtome. In: Tübingen, M. U. (ed). LeicaBiosystems, Vol. 95.8807 Rev B - Order no. 1495.8807 Tübingen. 